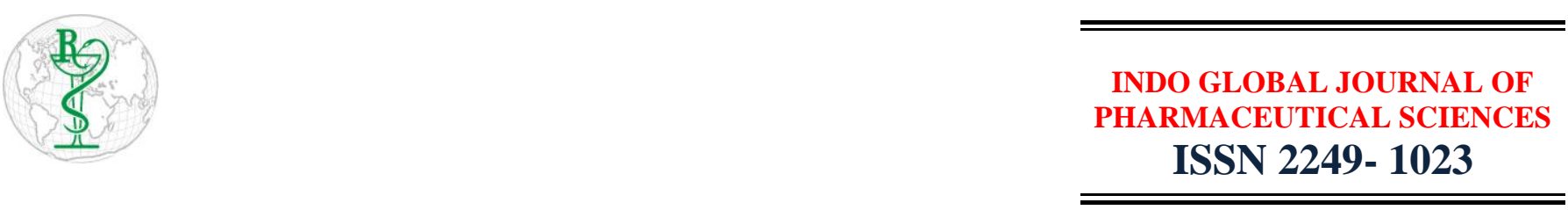

\title{
Nanoparticles Characterization and Applications: An Overview
}

Address for Correspondence: Simardeep Kaur; simar.simardeep.1998@gmail.com

\begin{abstract}
Received:
01.03.2019

Accepted:

25.03.2019

Keywords

Nanotechnology;

Nanoformulation

$\mathrm{s}$; Polymer

Chemistry.
\end{abstract}

\author{
Simardeep Kaur *, Parampal Kaur \\ Sri Sai College of Pharmacy, Manawala, Amritsar-143115, Punjab, India
}

\begin{abstract}
In recent years the potential use of polymeric nanoparticles as carriers for a wide range of drugs for therapeutic applications has been increased due to their versatility and wide range of properties. It has great interest in wide variety of applications in the field of information, energy, environment and medical technology. Due to their unique properties intended primarily on size, composition and structure. Nanoparticles ranges between $1 \mathrm{~nm}-100 \mathrm{~nm}$ in size. Nanotechnology explores electrical, optical and magnetic activity as well as structural behavior at the molecular and sub-molecular level. This study aims to present an overview of nanoparticles, with special reference to their mechanism of biosynthesis and types. (C) 2019 iGlobal Research and Publishing Foundation. All rights reserved.
\end{abstract}

Cite this article as: Kaur, S.; Kaur, P. Nanoparticles Characterization and Applications: An Overview. Indo Global J. Pharm. Sci., 2019; 9(2Suppl.): 146. DOI: http://doi.org/10.35652/IGJPS.2019.92S44 .

Indo Global Journal of Pharmaceutical Sciences( ISSN 2249 1023; CODEN- IGJPAI; NLM ID: 101610675) indexed and abstracted in CrossRef (DOI Enabling), UGC CARE Journal List, EMBASE(Elsevier), National Library of Medicine (NLM) Catalog, ResearchGate, Publons, CAS (ACS), Index Copernicus, Google Scholar and many more. For further details, visit http://iglobaljournal.com

This is a special issue as an outcome of 'RAPSCON-2019' sponsored by APTI and organized by Sri Sai College of Pharmacy, Manawala, Amritsar, Punjab, India. Relaxation offered in journal format. 